\title{
K NĚKTERÝM OTÁZKÁM VÝVOJE STÁTNÍHO OBČANSTVÍ NA ÚZEMÍ DNEŠNÍHO STÁTU IZRAEL A NA PALESTINSKÉM ÚZEMÍ
}

\author{
VERONIKA D'EVEREUX
}

\begin{abstract}
Selected Issues of the Development of the Citizenship in the Territory of Today's State of Israel and the Palestinian Territories

Two nations might have a "genuine link" towards the territory of the current states of Israel and Palestine. The Arab nation is considered to be the indigenous peoples. The members of the Jewish nation in accordance with the League of Nations diction, began the emigration process in the 20th century in connection to the so-called "law of return" to Palestine, which was historically considered their national homeland. During the past hundred years, political development have led to numerous changes in relation to the citizenship of the subjects living in the territory of Mandate Palestine. The first milestone was the creation of the State of Israel and the second one was the emergence of the state of Palestine. Legal issues related to the citizenship of the Palestinian population are not effectively codified and defined until this day.
\end{abstract}

Keywords: Jewish nation; Arab nation; citizenship; nationality; travel documents

Klíčová slova: židovský národ; arabský národ; státní př́islušnost; národnost; cestovní dokumenty

DOI: $10.14712 / 23366478.2020 .26$

\section{1. ÚVOD}

Národ je tvořen osobami, které pojí společný původ, ${ }^{1}$ jazyk a kultura, a sice prostřednictvím přesvědčení o pospolitosti a soudržností mezi jeho členy, které dále pojí společná identita odpovídající předchozímu historickému vývoji a významným událostem, které na jeho formování měly vliv. V př́padě vzniku státu je jeho obyvatelstvo tvořeno jednotlivci, kteří byli formováni jako národ. Na vznik státu lze nahlížet i tak, že je výstupem politického jednání národa. Zároveň ale může být v souvislosti se vznikem státu formován národ nový. Mezi základní rysy demokratického státu patří i zákaz diskriminace obyvatel, kteří nejsou součástí jeho kulturního a národního dědictví. ${ }^{2}$ Jedním ze základních rysů státu je podle zásady svrchovanosti i výkon

1 MALENOVSKÝ, J. Mezinárodní právo veřejné, jeho obecná část a poměr $k$ jiným právním systémům, zvláště k právu českému. Brno: Doplněk, 5., podstatně upravené a doplněné vydání, 2007, s. 166.

2 KHALIL, A. Palestinian Nationality and Citizenship. In: CARIM Research Report, European University Institute, Robert Schuman Centre for Advanced Studies. [online] 2001, s. 1-3 [cit. 2019-02-17]. Dostupné na: https://papers.ssrn.com/sol3/papers.cfm?abstract_id=1559205. 
personální jurisdikce teritoriálního státu vůči jeho obyvatelům, kteří se stávají občany tohoto státu. ${ }^{3}$

V mezinárodním právu má státní občanství význam v podobě trvalého připoutání jednotlivce k určitému státu, toto trvalé připoutání umožňuje určit mezinárodně právní závazky a oprávnění daného státu v oblasti problematiky státního občanství. ${ }^{4} \mathrm{~V}$ odborné literatuře lze nalézt několik pojmů, které se často používají jako synonyma, někdy se ovšem odlišují. Jsou jimi pojmy státní příslušnost („nationality“) a státní občanství (,citizenship“). Odlišnost mezi obsahem pojmů státní příslušnosti a státního občanství lze shledat především v souvislosti s výkladem těchto pojmů v kontextu mezinárodního a vnitrostátního práva. Mrázek uvádí, že státní př́islušnost indikuje mezinárodně právní př́slušnost jednotlivce ke státu, která byla původně feudálním poddanstvím jednotlivce k panovníkovi, a později ke státu, naopak státní občanství je prvkem práva vnitrostátního. ${ }^{5} \mathrm{~V}$ oblasti common law se uplatňovalo spojení jednotlivce s vladařem, vůči němuž byl jednotlivec zavázán svou věrností a byl v podřízené pozici. Tomu patrně odpovídá i označení občana termínem jak ,subject", tak i ,national“. Oppenheim uvádí, že státní př́islušnost jednotlivce jej charakterizuje jako poddaného (,,subject ${ }^{\text {") }}$ určitého státu a tím i jeho občana, ${ }^{6}$ pojmy subjekt a občan považuje z pohledu mezinárodního práva za synonyma. ${ }^{7}$ Klade ovšem důraz na rozlišování pojmů ,nationality“ a „citizenship“ ve smyslu občanství, tj. vztahu jedince ke státu (a tudíž ve vztahu k státní příslušnosti jednotlivce), od pojmu ,nationality“ ve smyslu příslušnosti k určitému národu či ve smyslu etnického původu. ${ }^{8}$ Jako příklad uvádí, že ačkoliv jsou Angličani, Skotové a Irové přes jejich odlišný etnický původ občany Velké Británie (,British nationality as regards their citizenship“), naopak př́slušníci polské národnosti („nationality“) byli na konci 18. století občany Ruska, Rakouska a Pruska (užší obsah pojmu „nationality“ toliko ve významu , citizenship“) ${ }^{9}$

Mezinárodně právní instrumenty používají častěji výraz státní př́islušnost (,,nationality“), nicméně např. v případě Haagské úmluvy o jistých otázkách vztahujících se ke konfliktu zákonů o státní př́íslušnosti z 12.4. 193010 došlo $\mathrm{k}$ př́ekladu této úmluvy do českého jazyka jako Úmluvy o střetů zákonů o „státním občanstvi““, která v čl. 1 stanoví, že je věcí každého státu určit svým zákonodárstvím, kdo jsou jeho státní př́íslušníci (a tato státní př́islušnost musí být uznána jinými státy za podmínky, že je též v souladu

3 POTOČNÝ, M. - ONDŘEJ, J. Mezinárodní právo veřejné - Zvláštní část. Praha: C. H. Beck, 2006, s. 45. Srov. OPPENHEIM, L. International Law a Treatise. Vol. 1 Peace. London, New York and Bombay: Longmans, Greens and Co. 1905, s. 341.

4 ČEPELKA, Č. - ŠTURMA, P. Mezinárodní právo veřejné. Praha: C. H. Beck., 2008, s. 326

5 MRÁZEK, J. Úloha státní příslušnosti a otázky státního občanství v mezinárodním právu. In: ŠTURMA, P. - TYMOFEYEVA, A. Státní občanství v kontextu vývoje lidských práv. Praha: Karlova univerzita, 2017, s. 28-29.

6 OPPENHEIM, L. International Law a Treatise. Vol. 1 Peace. London, New York and Bombay: Longmans, Greens and Co. 1905, s. 348.

7 OPPENHEIM, c. d. s. 349.

8 Srov. MRÁZEK, c. d. s. 29.

9 Pozn. v angl. originále ,,nationality qua citizenship“ OPPENHEIM, c. d. s. 349.

10 POTOČNYY, M. - ONDŘEJ, J. Obecné mezinárodní právo v dokumentech. Praha: C. H. Beck, 4. doplněné vydání, 2016, s. 35. 
s mezinárodním právem). ${ }^{11} \mathrm{~V}$ autentickém textu je použit pojem ,nationals“ a v českém překladu „občané““.

Státní občanství lze v neposlední řadě chápat rovněž jako jedno ze základních lidských práv (např. v čl. 15 Všeobecné deklarace lidských práv ${ }^{12}$ je uvedeno, že každý má právo na státní příslušnost, resp. v originále na ,nationality“, podobnou úpravu lze nalézt i v dalších mezinárodněprávních smluvních pramenech.) ${ }^{13} \mathrm{~V}$ oblasti evropského práva, např. v Evropské úmluvě o státní prŕíslušnosti, došlo do českého jazyka k překladu tohoto dokumentu jako úmluvy o státním občanství, v čl. 4 (a) je stanoveno, že každý má právo na státní př́íslušnost (v českém překladu „na státní občanství“), v čl. 3 (1) každý stát rozhoduje, kdo jsou jeho státní př́íslušníci (v českém překladu „občané“), či v čl. 4 (c) nikdo nesmí být zbaven své státní příslušnosti (v českém překladu „občanství") atd. ${ }^{14}$

Autorka se domnívá, že detailní teoretické zkoumání významu, výkladu a aplikace pojmů státní příslušnost a státní občanství lze nalézt v celé řadě již existujících pramenů a není možné v rozsahu jejího př́íspěvku tento aspekt vyčerpat, $\mathrm{z}$ toho důvodu si autorka dovolí používat pojmy státní příslušnost a občanství jako synonyma.

Tento příspěvek je zaměřen na vývoj a proměny (pravidla nabývání a pozbývání) státního občanství osob žijících na území dnešních států Izrael a na okupovaném palestinském území. Autorka si v žádném smyslu nenárokuje v rozsahu tohoto př́íspěvku zahrnout všechny detaily související s proměnami právní úpravy v této oblasti. Cúlem příspěvku je provést čtenáře stěžejními událostmi právního vývoje spojeného s proměnami v oblasti státního občanství osob žijících na tomto území a poskytnout základní přehled v této problematice. Dle názoru autorky předmětné právní události posledních přibližně sto let zásadním způsobem ovlivňují i současnou právní a politickou situaci. Zcela záměrně je téma pro účely tohoto příspěvku zúženo dle geografického hlediska a zahrnuje toliko aspekty související se státní příslušností osob žijících na území zahrnující oblasti Pásma Gazy, Západního břehu, Jeruzaléma a státu Izrael. Naopak jsou vyloučeny právní otázky související s palestinskou menšinou žijící v sousedních arabských státech, především v Sýrii, Jordánsku, Libanonu, Egyptě a některých dalších zemích. Zároveň je také vyňata problematika palestinských uprchlíků požívajících mezinárodní ochranu od OSN, a sice z důvodu značné obsáhlosti tohoto tématu, jehož zpracování by si dle názoru autorky jistě zasluhovalo podobu např. samostatného příspěvku.

11 ČEPELKA - ŠTURMA, c. d. s. 327.

12 OSN. Všeobecná deklarace lidských práv. [online] 1948. [cit. 2018-12-23]. Dostupné na: http://www .lidskaprava.cz/uploads/03_dokumenty/04_uvod/00_VDLP_UDHR-.pdf.

13 Např. v čl. 20 Americké úmluvy o lidských právech z roku 1969, v čl. 24 (3) Mezinárodního paktu o občanských a politických právech z roku 1966, v čl. 7 Úmluvy o právech dítěte z roku 1980, v čl. 5 d iii Úmluvy o odstranění všech forem rasové diskriminace z roku 1965 atd.

14 MRÁZEK, J. c. d. s. 32. 


\section{OBČANSTVÍ OSOB ŽIIÍCÍCH NA PŘEDMĚTNÉM ÚZEMÍ PO ROZPADU OSMANSKÉ ŘíŠE V LETECH 1917-1922}

Prameny vztahující se k „palestinskému občanství“, resp. „palestinské státní příslušnosti“ lze nalézt v období mandátní správy před vznikem státu Izrael. Pojetí palestinského občanství v tomto původním slova smyslu se zásadním způsobem odlišuje od současného chápání významu pojmu „Palestinci“ či „obyvatelé Palestiny“ eventuálně „občané Palestiny“, jinými slovy těch osob arabského původu žijících na okupovaném území Západního břehu (vč. Východního Jeruzaléma) a Pásma Gazy. „Palestinské občanství“ z dnešního úhlu pohledu se zásadně odlišuje od předchozích státních občanství arabských obyvatel žijících na území dnešního státu Izrael a území Palestiny. 15

„Palestinské občanství“v dnešním slova smyslu má dle Khalila čtyři specifika, kterými se liší od občanství osob žijících v sousedních arabských státech. První zvláštností je skutečnost, že Palestinci jsou jediní Arabové, jejichž „stát“16 je ve výkonu své suverenity na svém území omezen státem jiným. ${ }^{17}$ Za druhé, přítomnost trvající a neukončené izraelské okupace způsobila vznik asociace pojmu palestinské příslušnosti s bojem o nezávislost a potažmo s tím spojený i výkon práva na sebeurčení. Za třetí, izraelská okupace je vnímána arabskými státy (a také jejich občany) a většinou mezinárodního společenství jako protiprávní. Konečně za čtvrté, existuje trvající problém spojený s miliony palestinských uprchlíků žijících v uprchlických táborech a v zahraničí. ${ }^{18}$

Území dnešního státu Izrael a okupované palestinské území bylo od počátku šestnáctého století do roku 1917 součástí Osmanské říše. Prvním pramenem souvisejícím s úpravou státního občanství pro obyvatele území této říše, které zahrnovalo také dotčené území, je osmanská ústava z roku 1876, ${ }^{19}$ podle jejíhož čl. 8 jsou obyvatelé předmětného území nositeli osmanské státní prř́slušnosti (,subjects of Ottoman Empire"). 20

V důsledku porážky Osmanské říše v první světové válce - Velkou Británií roku 1917 - došlo k ukončení výkonu jak územní, tak i personální suverenity Osmanské říše také vůči území dnešního státu Izrael a vůči palestinskému území. V roce 1916 byla uzavřena dohoda mezi Velkou Británií a Francií, s pozdějším souhlasem Ruska. Tato dohoda je známá pod názvem Sykesova-Picotova dohoda, podle které pro případ porážky

15 Srov. KHALIL, c. d. s. 4-5.

16 Pozn.: V nauce mezinárodního práva se různí názory na to, zda je či není Palestina státem z pohledu mezinárodního práva. Autorka se této otázce věnuje blíže v kapitole páté. Skutečnost, že na tomto místě použila ve spojení s palestinským občanstvím slovo stát (myšleno stát Palestina), neznamená, že se autorka domnívá, že Palestina je z pohledu mezinárodního práva státem, autorka toliko odkazuje na př́íspěvek A. Khalila.

17 Srov. Khalil doslova uvádí „, the Palestinian people are the only Arabs without their own state“, KHALIL, c. d., s. 9.

18 Tamtéž, s. 9-11.

19 The Ottoman Constitution, Promulgated the 7th Zilbridje, 1293 (11/23 December, 1876. In: JSTOR [online] [cit. 2019-12-22]. Dostupné na: https://ia801700.us.archive.org/35/items/jstor-2212668/2212668.pdf.

20 HANLEY, W. What Ottoman Nationality Was and Was Not. In: Journal of the Ottoman and Turkish Studies Association [online] Bloomington, vol. 3, No. 2, 2016, s. 277-298 [cit. 2019-02-18]. Dostupné na: https://www.jstor.org/stable/10.2979/jottturstuass.3.2.05?seq=1\#page_scan_tab_contents. 
Osmanské říše mělo dojít k uznání nezávislého arabského státu nebo konfederace na území dnešních států Izrael a Palestina. Dále bylo dojednáno rozdělení vlivu, záštity a administrativní správy území Osmanské říše zúčastněnými státy Trojdohody. V období let 1917 až 1918 Velká Británie na území Palestiny uvalila vojenskou okupační správu, následně do roku 1921 civilní okupační správu, od roku 1922 došlo k vytvoření mandátní správy trvající do roku $1948 .^{21}$

Mezi právně relevantnî́2 ${ }^{22}$ prameny týkající se uspořádání území Palestiny vč. území Jeruzaléma lze řadit čl. 22 Paktu o Společnosti národů, ${ }^{23}$ který uvádí, že určitá území oddělená od Turecka by mohla být prozatímně uznána za nezávislá s tím, že budou předmětem administrativní správy a budou požívat podpory mandatáře po dobu, dokud tyto subjekty nebudou schopny plné samostatnosti.

Do ustanovení čl. 95 mírové smlouvy ze Sevres ${ }^{24}$ v Turecku z 10. 8. 1920 je zahrnuto ustanovení čl. 22 Paktu o Společnosti národů, dle něhož má být budoucí správa Palestiny realizována prostřednictvím dohody mezi spojenými vítěznými mocnostmi, které zvolí mandatáře. Mandatář bude zodpovědný za výkon deklarace britské vlády z 2. 11. 1917, tj. Balfourovy deklarace, jež byla spojenci přijata s účelem umožnění vzniku Palestiny jakožto národní domoviny pro židovský národ. ${ }^{25}$ Podle ustanovení čl. 129 této smlouvy Židé žijící na území Palestiny mající jinou než tureckou státní příslušnost se stanou s okamžikem vstupu této smlouvy v platnost občany Palestiny. Vlivem revoluce v Turecku nebyla mírová dohoda ze Sevres nikdy ratifikována a do smlouvy z Lausanne se tento článek v totožné podobě nepromítl.

Společnost národů nicméně dne 24. 6.1922 přijala podmínky britského mandátu Palestina s účinností k 29. 9. 1923. Stalo se tak ještě před tureckou ratifikací smlouvy z Lausanne, ${ }^{26}$ jež nahrazovala smlouvu ze Sevres, která nikdy nevešla v platnost. Smlouva z Lausanne stanovila hranice Turecka totožné s jeho současnými hranicemi, neodkazovala ovšem ani na čl. 22 Paktu Společnosti národů ani na Balfourovu deklaraci. V článku 16 smlouvy z Lausanne ${ }^{27}$ ze dne 24. 7. 1923 Turecko činí jednostranné prohlášení, jímž se zrríká veškerých teritoriálních nároků v oblasti provincie Palestiny. V tomto prohlášení není stanoveno, v čí prospěch se tohoto území zříká. Z toho důvodu

21 GINAT, A. British Mandate for Palestine. In: International Encyclopedia of the First World War, Freie Universität Berlin. [online] Berlin, 2018. [cit. 2019-02-17]. Dostupné na: https://encyclopedia.1914-1918 -online.net/article/british_mandate_for_palestine.

22 V této souvislosti existují i další dokumenty, kterými jsou politická prohlášení nemající vliv na právní status provincie Palestiny. Jsou jimi např. korespondence mezi vysokým britským komisařem v Egyptě sirem Henrym McMahonem a Sharifem Husseinem, dohoda mezi Weiymannem a Fajsalem z 3. 1. 1919. Po vyhnání osmanských vojsk vykonávala Velká Británie fakticky státní moc nad provincií Palestina, ovšem v pozici válečné okupační síly dle ustanovení čl. 42 a 56 Řádu války pozemní z roku 1907, viz ČEJKA, M. Izrael a Palestina. Brno: Barrister and Principal, 2013, s. 32-38.

23 Mírová smlouva mezi mocnostmi spojenými a sdruženými a Německem a Protokol podepsaný ve Versailles dne 28. června 1919. 217/1919 Sb., znění účinné od 10.01. 1920 do 1. 1. 1945. [online] 2019. [cit. 2019 -02-17]. Dostupné na: https://www.beck-online.cz/bo/chapterview-document.seam?documentId= onrf6mjzgiyv6mrrg4wta. Alternativně lze nalézt český překlad Paktu o Společnosti národů např. In: Schelle, K. Moderní dějiny státu a práva v dokumentech. Brno: Masarykova univerzita, 1992, s. 53-61.

24 MARTIN, L. The Treaties of Peace 1919-1923. Vol. II, New York : Carnegie Endowment for International Peace, 1924.

25 Srov. KHALIL, c. d., s. 18.

26 MARTIN, c. d.

27 Treaty of Peace with Turkey and Other Instruments (1923). 
nelze jednoznačně určit právního nástupce, dle této smlouvy bude status území pro futuro upraven dotčenými stranami, bez další konkretizace zúčastněných stran. Mezinárodní právo uznává jednostranné vzdání se práva nad územím, toto právo náleží suverénnímu státu, účinky takového vzdání se práv vůči území nastanou v okamžiku uznání tohoto vzdání se územní suverenity ostatními smluvními stranami. ${ }^{28}$ Podle ustanovení čl. 35 smlouvy z Lausanne budou mít Židé jiné než turecké státní př́íslušnosti, kteří mají trvalý pobyt na území Palestiny v době vstupu této smlouvy v platnost, právo stát se občany Palestiny, pakliže si tuto státní příslušnost zvolí a splní budoucím zákonem stanovené podmínky. ${ }^{29}$

Výše uvedené prameny smluvní úpravy týkající se palestinského občanství se tedy zásadním zpo̊sobem odlišovaly. Smlouva ze Sevres, pakliže by vstoupila v platnost, by obsahovala mnohem př́iznivější či jednodušší úpravu pro nabývání palestinské státní př́islušnosti pro osoby židovského původu. Naopak dle právně účinné smlouvy z Lausanne museli Židé splnit další podmínky, které zahrnovaly trvalý pobyt, volbu státního občanství a případně ještě další zákonné podmínky. Tato smluvní formulace mohla mít vliv na židovské přistěhovalectví, které v době vstupu smlouvy z Lausanne v platnost probíhalo již ve třetí vlně (celkový počet židovských imigrantů byl ke konci roku 1923 přibližně sto dvacet pět tisíc).

V průběhu vojenské okupace Palestiny v letech 1917 až 1922 přistoupila Velká Británie v souvislosti se správou území k vystavování provizorních dokladů - jednalo se o cestovní doklady a pasy - stvrzujících státní př́íslušnost obyvatel Palestiny, jež zaručovala právo diplomatické ochrany obyvatelům Palestiny cestujícím do zahraničí, a v neposlední řadě jasně oddělila režim vstupu na území Palestiny pro její obyvatele a cizince, a rovněž upravila př́stup tamních obyvatel k politickým právům a získání práva trvalého pobytu. Držitel palestinských dokladů vydaných v tomto období mohl být ten, kdo se narodil v Palestině, či jehož otec se narodil v Palestině, dále ten, kdo projevil zájem optovat palestinskou státní příslušnost poté, co bude do budoucna přijat vnitrostátní předpis upravující palestinské občanství, a konečně ten, kdo zamýšlel se v Palestině trvale usadit. Vystavování palestinských cestovních dokumentů osmanským občanům, jejichž státní příslušnost již pozbyla účinnosti, bylo formálně upraveno v srpnu 1920. Postupně došlo i k běžnému užívání termínů „Palestinec“ a „,palestinský občan“. Quafisheh uvádí, že lze hovořit o de facto palestinské státní příslušnosti. ${ }^{30}$ Dne 26. 8. 1920 byla přijata pravidla pro imigraci do Palestiny, která upravovala podmínky vstupu zahraničních osob do Palestiny, a především procesní postup imigrace. Tento předpis užívá termín ,palestinský občan“ (čl. 8) a „osoba s trvalým pobytem v Palestině“ (čl. 5), 31 význam těchto pojmů byl vyložen v pozdější právní úpravě z roku 1925

28 Hanko, J. Teritoriální nárok v Palestině. In: Šturma, P. Mezinárodní právo a státní území. Praha: Univerzita Karlova, Právnická fakulta, 2015, s. 150-152.

29 Srov. QAFISHEH, M. Genezis of Citizenship in Palestine and Israel. Palestinian Nationality in the 1917-1925 Period. In: Journal of the Historiy of International Law. [online] 2009, 11, s. 10, 14-18 [cit. 2019-02-19]. Dostupné na: https://journals .openedition.org/bcrfj/6405.

30 QAFISHEH, c. d. s.6-8.

31 BRITISH GOVERNMENT. Report of the High Commissioner on the Administration of Palestine, 1920-1925. London: His Majesty's Stationary Office, 1925, s. 3-59. 
vytvořené správcem mandátu Palestina. Podle Quafishehe došlo ke vzniku palestinské státní příslušnosti již na počátku vojenské okupace Palestiny v roce 1917, de facto byl tento termín vytvořen $\mathrm{v}$ souvislosti s britskou vojenskou správou území v dočasném režimu, ačkoliv de jure a v souladu s obecným mezinárodním právem byli obyvatelé Palestiny i nadále občany Osmanské říše.

\section{KODIFIKACE PALESTINSKÉHO OBČANSTVÍ V PU゚VODNÍM SLOVA SMYSLU V SOUVISLOSTI S MANDÁTNÍ SPRÁVOU V LETECH 1922-1948 A VYHLÁŠENÍM NEZÁVILOSTI STÁTU IZRAEL}

V období let 1922-1948 vykonávala správu mandátu Palestina Velká Británie. Výkon správy měl být zaměřen na rozvoj území k blahu jeho obyvatel, dokud nebude vytvořena jiná dohoda mezi Společností národů (od roku 1946 Organizací spojených národů) a správcem mandátu. ${ }^{32}$

\subsection{PRÁVNÍ ÚPRAVA V OBDOBÍ MANDÁTNÍ SPRÁVY}

V rámci mandátní správy byla Velkou Británií přijata 10. 8. 1922 právní úprava s názvem Palestine Order-in Council ${ }^{33}$ pro fungování Palestiny, která svou povahou mohla připomínat ústavu. ${ }^{34}$ Palestine Order-in Council zahrnoval funkční ustanovení, jež obsahovalo definici pojmu ,cizinec“, a sice v čl. 59 (1), podle něhož je cizinec osoba jakéhokoliv původu (,,national“) a státní prŕíslušník (,,subject") evropského, amerického či japonského státu a zároveň není původním obyvatelem území spravovaného evropským státem v mandátním režimu, není osmanským státním příslušníkem, a není osobou, která pozbyla osmanské občanství a nenabyla občanství jiného státu. ${ }^{35} \mathrm{Z}$ této definice vyplývá, že obyvatelé Palestiny byli i nadále osmanskými občany, v praxi poŽívajícími ochranu Velké Británie. ${ }^{36}$

Ve vztahu k území dnešních států Izrael a Palestina došlo v návaznosti na čl. 22 Paktu Společnosti národů ${ }^{37}$ k implementaci uznání historického spojení židovského národa s územím Palestiny a vytvoření právního základu k obnovení národní domoviny židovského národa v Palestině. Do mandátu Palestina byla včleněna tzv. Balfourova

32 CASSESE, A. Legal Consideration on International Status of Jerusalem In: CASSESE, A. - GAETA, P. - ZAPPALA, S. The Human Dimension of International Law: Selected Papers of Antonio Cassese. Oxford: Oxford University Press, 2008, s. 17.

33 George V of the United Kingdom. The Palestine Order in Council, 1922. In: UNISPAL [online] digitalizováno 18/01/2015, [cit. 2019-12-22]. Dostupné na: http://unispal.un.org/UNISPAL.NSF/0 /C7AAE196F41AA055052565F50054E656.

34 Srov. QAFISHEH, c. d., s. 11.

35 George V of the United Kingdom. The Palestine Order in Council, 1922. c. d.

36 Srov. QAFISHEH, c. d., s. 12.

37 Mírová smlouva mezi mocnostmi spojenými a sdruženými a Německem a Protokol podepsaný ve Versailles dne 28.června 1919.217/1919 Sb., znění účinné od 10.01. 1920 do 1.1.1945. c. d. 
deklarace, ${ }^{38}$ podle jejíhož článku 6 a 7 současně s respektováním a bez poškození práv stávajících obyvatel má správce Palestiny umožnit, podporovat a vytvořit podmínky pro židovské přistěhovalce a zajištění palestinského občanství vč. práva trvalého pobytu pro ty osoby židovského původu, jež se rozhodnou do Palestiny přesídlit. ${ }^{39}$ Zároveň je správce Palestiny dle čl. 7 zodpovědný za přijetí právní úpravy regulující státní občanství, které má zahrnovat ustanovení o možnosti získání palestinského občanství osobám židovského původu, které si zvolí Palestinu jako zemi svého trvalého pobytu. ${ }^{40}$

V čl. 7 textu mandátu Palestina obsahujícím ustanovení o státním občanství jsou použity pojmy „,nationality“ a ,citizenship“ jako synonyma, což dle Quafishehe předpokládá př́tomnost právního vztahu mezi jednotlivci a Palestinou pod mandátní správou. Původnost vazby k palestinskému území (,nationality“) tedy neměla vliv na rasové, náboženské či politické odlišnosti místních obyvatel. Proto dle Quafishehe nelze postavit rovnítko mezi palestinským občanstvím (,,citizenship“) a státním občanstvím garantovaným osobám židovského původu na základě čl. 7 textu mandátu, a sice z důvodu, že palestinské státní občanství bylo dříve, v době vojenské okupace Palestiny v letech 1917 až 1922, ačkoliv jen de facto, používáno pro obyvatele Palestiny arabského původu. ${ }^{41}$ Židovští imigranti by tedy nemohli palestinské státní občanství získat, pokud by nesplnili podmínku trvalého usazení se v Palestině, na rozdíl od obyvatel arabského původu, kteří tuto podmínku splňovat nemuseli. ${ }^{42}$

K právně účinné změně státního občanství obyvatel dnešních států Izrael a Palestina z osmanské státní příslušnosti na palestinskou státní př́íslušnost ${ }^{43}$ došlo prostřednictvím vnitrostátního aktu Palestinian Citizenship Order $^{44}$ z 1. 8. 1925, podle jehož čl. 1 osmanští občané mající místo svého obvyklého pobytu na území mandátu Palestina, automaticky získali palestinskou státní příslušnost. ${ }^{45}$

Občané Osmanské říše, kteří na základě výše uvedené úpravy získali palestinské státní občanství, pocházeli z několika národnostních skupin. První skupinu tvořili drobní arabští rolníci, pastevci a beduíni, ${ }^{46}$ kteří žili kočovným způsobem života také na území dnešního státu Izrael a palestinského území. Autorka shledává důležitým výraz „také“, protože kočovný způsob života putujícího obyvatelstva ${ }^{47}$ svou podstatou vylučuje trvalé připoutání národa k určitému území. Obecným předpokladem je tedy

38 BALFOUR, A. J. Balfour Declaration, 1917. In: Yale Law School, Lillian Goldman Law Library, The Avalon Project [online] 1922 [cit. 2019-12-22]. Dostupné na: https://avalon.law.yale.edu/20th_century/balfour.asp.

39 LEAGUE OF NATIONS. The Palestine Mandate. In: Yale School of Law, Lillian Goldman Library, The Avalon Project, Documents in Law, History and Diplomacy. [online] 1922 [cit. 2019-02-19]. Dostupné na: http://avalon.law.yale.edu/20th_century/palmanda.asp.

40 LEAGUE OF NATIONS. The Palestine Mandate. c. d., srov. QAFISHEH, M., c. d., s. 10.

41 Srov. KHALIL, c. d., s. 18-22.

42 QAFISHEH, c.d., s. 10.

43 Tamtéž, s. 5.

44 Legislation of Palestine, Vol. 1., s. 37, Laws of Palestine, s. 3404 a Palestinian Gazette, No. 1351, Supplement 2, 10. 8. 1944, s. 912

45 BANKO, L. Nationality and Citizenship in Mandate Palestine In: Ottoman History Podcast [online] 2016. [cit. 2019-02-19]. Dostupné na: http://www.ottomanhistorypodcast.com/2016/10/citizenship-in-mandate-palestine.html.

46 CEJKA, c. d., s. 28.

47 MALENOVSKÝ, J. Mezinárodní právo veřejné, jeho obecná část a poměr k jiným právním systémům, zvláště k právu českému. Brno: Doplněk, 2004, s. 167-168. 
trvalé spojení obyvatelstva s územím, obyvatelstvo by se nemělo stále přesunovat, proto lze uvažovat v obecné rovině o tom, že kočovníci obyvatelstvem nejsou. Pro srovnání lze ovšem uvést případ kočovných kmenů na území Západní Sahary, kdy Mezinárodní soudní dvůr prohlásil, že tamní kočovné kmeny obyvatelstvo představují, a to z důvodu, že jsou sociálně a politicky organizovaní ${ }^{48}$ Další a méně početnou skupinou původního obyvatelstva $\mathrm{v}$ předmětném období byli obyvatelé židovského původu, kteří od konce 15. století žili na území Mamelucké a později Osmanské ř́řše jako cizinci a nositelé zvláštní daňové povinnosti. ${ }^{49}$

Ustanovení mandátu Palestina, konkrétně části obsahující inkorporovanou Balfourovu deklaraci, dále upravovalo možnost nabytí palestinského státního občanství z titulu emigrace, která byla umožněna pouze osobám židovského původu..$^{50}$ Mandát explicitně nezakládal možnost nabytí palestinského občanství naturalizací osobám jiného než židovského původu. ${ }^{51}$

\subsection{PRÁVNÍ ÚPRAVA PO VZNIKU STÁTU IZRAEL}

Vznik státu Izrael představuje výjimku v mezinárodním právu z důvodu, že k jeho vzniku došlo v souvislosti s právně nezávaznou rezolucí orgánu mezinárodní organizace, konkrétně s rezolucí VS OSN 181 (II). Tato rezoluce navrhovala rozdělení území mezi dva budoucí státy, stát židovský a arabský. Podle ustanovení izraelské deklarace nezávislosti z roku 1948 byli arabští obyvatelé státu Izrael vyzváni k aktivní účasti na vzniku státu Izrael jakožto právoplatní a rovní občané, kteří se mají účastnit na politickém životě ve všech provizorních a trvalých institucích. ${ }^{52}$

Ve spojitosti s vyhlášením nezávislosti státu Izrael 14.5. 1948 přistoupily sousední arabské státy k ozbrojené invazi vǔči nově vzniklému židovskému státu, který měl prostřednictvím rezoluce Valného shromáždění 181 (II) vymezenou část území bývalého mandátu Palestina, zatímco zbývající byla vyhrazena pro nový arabský stát, ${ }^{53}$ jehož vznik se započal realizovat teprve po událostech roku 1988, kdy se Jordánsko definitivně vzdalo územního nároku vůči Západnímu břehu. ${ }^{54}$

Z důvodu, že nedošlo současně ke vzniku jak státu Izrael, tak státu Palestina, se musel nově vzniklý stát Izrael vypořádat s problémem udělování izraelského občanství odlišně od původní vize svých zakladatelů, kdy by „palestinské“ v nynějším smyslu izraelské občanství bylo udělováno pouze emigrantům židovského původu v podobě tzv. práva návratu (, law of return“" ${ }^{55}$ odvozeného od principu ochrany před stíháním

\footnotetext{
48 ŠTURMA, P. a kol. Casebook Výběr případi̊ z mezinárodního práva veřejného. Praha: Univerzita Karlova v Praze, 2015, s. 79-82.

49 JOHNSON, P. Dějiny židovského národa. Praha: Rozmluvy, 1995, s. 138-409.

50 LEAGUE OF NATIONSL The Palestine Mandate. c. d.

51 QAFISHEH, c. d., s. 18.

52 APFEL, A. Israeli Arabs: History \& Overview. In: Jewish Virtual Library. [online] 2019. [cit. 2018-12-23]. Dostupné na: http://www.jewishvirtuallibrary.org/history-and-overview-of-israeli-arabs.

53 UNITED NATIONS. Resolution 181 (II). Future Government of Palestine [online] 2019. [cit. 2018-12-23]. Dostupné na: https://unispal.un.org/DPA/DPR/unispal.nsf/0/7F0AF2BD897689B785256C330061D253.

54 GRIEF, H. The Legal Foundation and Borders of Israel umder International Law. A Treatise on Jewish Sovereignty over the Land of Israel. Jerusalem: Mazo Publishers, 2013, s. 183.

55 Srov. KHALIL, c. d., s. 25-26.
} 
a protiprávními zásahy do životů obyvatel židovského původu, tedy vůči subjektům, proti kterým byly uplatňovány Norimberské zákony v době nacistické diktatury. V mezinárodní praxi je možné, ačkoliv velmi vzácně, stát nepřijme související vnitrostátní právní úpravu ve vztahu k vytvoření občanství a vč. podmínek, za jakých mohou místní obyvatelé občanství získat. Absenci legislativy v případě arabských obyvatel žijících na území nově vzniklého státu Izrael odpovídala skutečnost nerealizace vzniku arabského státu tak, jak předpokládala rezoluce 181 (II), kterou odmítli jak tamní arabští obyvatelé, tak sousední arabské státy. V takovém případě je nezbytné, aby státy přijaly obyvatelstvo žijící na jejich území jako vlastní. ${ }^{56}$

Stát Izrael vznikl jako „národní domovina židovského národa“ a dle rezoluce 181 (II) měl být židovský stát vytvořen na ochranu suverenity židovského národa. ${ }^{57} \mathrm{~V}$ legislativě státu Izrael se vyskytují obsahově odlišné termíny státního občanství (,ezrahut“) a státní př́íslušnosti (,,le’om“). Dle výkladu Nejvyššího soudu státu Izrael je izraelský národ totožný s národem židovským (osobami židovského původu žijícími jak na území státu Izrael, tak i v diaspoře), a přiklání se tudíž k širšímu pojetí koncepce izraelského občanství, které může být uděleno na základě práva návratu „law of return“ kterékoliv osobě židovského původu cizí státní příslušnosti bez nutnosti splnění dalších podmínek. ${ }^{58} \mathrm{Na}$ osoby jiného než židovského původu, např. na původní obyvatele (a jejich potomky) území dnešního státu Izrael, se právo návratu nevztahuje.

Ve vztahu k původním arabským obyvatelům mandátu Palestina bylo přijato v roce 1953 ustanovení izraelského vnitrostátního práva, ${ }^{59}$ podle něhož jednotlivci, kteří žili na území státu Izrael ke dni jeho vzniku, získali izraelskou státní příslušnost, a to bez ohledu na jejich etnický původ.

Boiling uvádí v souvislosti se sukcesí států ve vztahu k obyvatelům území státu předchůdce tři pravidla mající povahu obyčejového práva, která jsou závazná pro všechny státy. Prvním je právo získat občanství státu nástupce, přičemž není vyloučeno, aby se toto pravidlo vztahovalo i na situace, v nichž co do právních účinků nefiguruje stát předchůdce a jedná se o př́ípad mezinárodní správy území. Druhým je povinnost zaručit právo návratu všem jednotlivcům, kteří se nacházeli v hostitelských státech či kteří byli odmítnuti jako cizinci k pobytu v jiném státu. Třetím je zákaz masového zbavení státní příslušnosti jako prostředek k přijetí jiných osob, které na základě svého původu jsou součástí národa, který byl jedním z hlavních důvodů k formování nového státního útvaru. 60

V případě původních arabských obyvatel předmětného území a jejich potomků došlo ovšem k hrubému porušení těchto pravidel. Konkrétní případy budou popsány níže. Ve stručnosti lze na tomto místě uvést, že ve vztahu k porušení prvního pravidla nedošlo

\footnotetext{
56 Srov. KHALIL, c. d., s. 26.

57 Tato rezoluce rovněž předpokládala vznik arabského státu na ochranu suverenity arabského (palestinského) národa.

58 Tamarin v. State of Israel, C. A. 630/70 (1972); srov. MRÁZEK, c. d., s. 41-42.

59 ISRAEL. Nationality Law. 5712-1952. In: Refworld, UNHCR. [online] 1953 [cit. 2018-12-23]. Dostupné na: https://www.refworld.org/docid/3ae6b4ec20.html.

60 BOILING, G. J. Palestinian Refugees and the Right of Return: An International Law Analysis. In: BADIL Information and Discussion Brief, Issue No. 8, s. [online] 2001 [cit. 2018-03-13]. Dostupné na: http:// www.badil.org/phocadownloadpap/Badil_docs/bulletins-and-briefs/Brief-No.8.pdf.
} 
dosud k vytvoření právně účinné úpravy, jež by definovala státní občanství osob arabského původu žijících mimo území státu Izrael, s čímž potažmo souvisí skutečnost, že existence „státu nástupce“ je spíše otázkou budoucího vývoje nežli soudobé reality. Porušení druhého pravidla odpovídá skutečnost, že stát Izrael nepočítá s možností repatriace uprchlíků, kteří z území dnešního státu Izrael odešli ve spojení s první arabsko-izraelskou válkou a šestidenní válkou. Zároveň není zřejmé, že by palestinské orgány v minulosti a současnosti usilovaly o možnost návratu osob, které požívají mezinárodní ochranu od OSN a žijí v uprchlických táborech. Jejich návrat se současně jeví jako spíše nerealizovatelný s ohledem jednak na jejich množství (původně cca tři čtvrtě milionu osob, dnes pět až šest milionů vlivem generačního růstu a rozvoje populace) a s ohledem na vnitřní problémy fungování Palestiny jakožto budoucího státu.

Částečné porušení třetího pravidla lze shledat jednak ve skutečnosti dočasného odebrání izraelského občanství osobám arabského původu a zároveň lze shledat případně i určitou „eventualitu vnímání nové izraelské legislativy jakožto budoucího porušení“. Konkrétně ve spojení s přijetím nového základního zákona, ${ }^{61}$ který mění určité aspekty denního života palestinských obyvatel např. ve vztahu k užívání úředních jazyků. Zásadní porušení lze ovšem shledat v případě masového odebrání jordánského státního občanství osobám žijícím na Západním břehu v roce 1988 ve spojení s aktem vyhlášení nezávislosti Palestiny. Autorka se domnívá, že zrušení státního občanství bylo velmi unáhleným aktem a představitelé Jordánska měli naopak jednat s představiteli Palestiny o přijetí dvoustranné smluvní úpravy, která by tuto otázku řešila.

\section{LEGISLATIVA UPRAVUJÍCÍ STÁTNÍ OBČANSTVÍ V NÁSTUPNICKÝCH STÁTECH BÝVALÉ OSMANSKÉ ŘÍŠE SOUSEDÍCÍCH S MANDÁTEM PALESTINA}

Rozpadem Osmanské říše vznikly na částech jejího území nové arabské státy, u nichž ve vztahu k území dnešního státu Izrael a palestinskému území byly v tomto období vymezeny i státní hranice. Jednalo se o Transjordánsko, Sýrii a Libanon. Hranice byly dále vymezeny i vưči Egyptu, který nebyl součástí Osmanské říše před jejím rozpadem. Egypt sdílí část společné hranice s dnešním palestinským Pásmem Gazy. Uvedené státy přijaly vlastní legislativu upravující státní občanství pro své obyvatele, čímž zároveň došlo i k vyloučení obyvatel mandátu Palestina z personální jurisdikce těchto států.

Vůči severním sousedům dnešního státu Izrael a území Palestiny, Sýrii a Libanonu, vykonávala Francie mandátní správu. 16. 12. 1923 byla v Jeruzalémě uzavřena dohoda mezi britským Vysokým komisařem pro Palestinu a francouzským Vysokým komisařem pro Sýrii a Libanon, jejímž předmětem bylo stanovení hranic budoucích států. ${ }^{62}$ Dále došlo 19. 1. 1925 k vytvoření vnitrostátních legislativních aktů týkajících se státního

61 Basic Law: Israel - the Nation State of the Jewish People, přijat v polovině roku 2018.

62 BENTWICH, N. Legislation of Palestine 1918-1925. Alexandria: Whitehead Morris Limited, Vol. II, 1926 s. 512. 
občanství v Sýrii a v Libanonu, ${ }^{63}$ z těchto zákonů vyplývalo, že nositelé libanonského a syrského občanství byli na území Palestiny považováni za cizí státní př́íslušníky, tímto aktem došlo tedy ke změně státní příslušnosti té části obyvatel bývalé Osmanské říše, která žila na území mandátu Sýrie a Libanonu.

Jihozápadní hranice dnešního státu Izrael a palestinského Pásma Gazy je sdílena s Egyptem, jehož autonomie byla Osmanskou říší uznána již na konci 19. století, formálně byla hranice stvrzena mezi těmito státy v roce 1906, z hlediska mezinárodního práva je významné uznání oddělení Egypta od Turecka ve smlouvě z Lausanne z roku 1923. Egypt přijal 23. 5. 1926 vnitrostátní předpis č. 26/1926 upravující egyptské občanství, podle něhož byla egyptská státní příslušnost stanovena retroaktivně již v roce 1914 prohlášením Velké Británie v pozici „,protektorátního správce“ Egypta. Podle pozdější úpravy z 19. 2. 1929 v zákoně č. 19/1929 se občané Osmanské říše, kteří měli místo svého obvyklého pobytu na území Egypta, k datu 5. 11. 1914 stali občany Egypta. ${ }^{64}$

Dle prvotních úvah o vypořádání části území bývalé Osmanské říše zahrnovalo území Transjordánska i území dnešního státu Izrael a palestinské území. K oddělení došlo 16. září 1922, kdy Rada Společnosti národů přijala rezoluci, ${ }^{65}$ kterou potvrdila návrh Velké Británie na oddělení Transjordánska od palestinského území a zároveň byla definována i hranice mezi těmito územími, kterou vymezovala řeka Jordán a Mrtvé moře. ${ }^{66}$ Dne 20. 2. 1928 uzavřela Velká Británie dohodu s jordánským emírem, jejímž předmětem bylo uznání autonomní transjordánské vlády současně za přítomnosti Velké Británie jakožto správce mandátu. Velká Británie tedy spravovala mandát Palestina a mandát Transjordánsko odděleně do roku 1946, kdy Jordánsko vyhlásilo svou samostatnost. Transjordánsko přijalo 23. 4. 1928 vnitrostátní úpravu o státní př́íslušnosti (Organic Law for Transjordan), dle čl. 4 byly nositeli transjordánského občanství („,Transjordan nationality") všichni osmanští obyvatelé žijící na území Transjordánska, a to retroaktivně k datu 6. 8. 1924, kdy vstoupila v účinnost smlouva z Lausanne. ${ }^{67}$ Tím zároveň došlo i k oddělení transjordánské státní příslušnosti od občanství palestinského.

Vztah mezi jordánským a palestinským občanstvím lze vyvodit také např. z rozsudku palestinského Nejvyššího soudu z 14. 12. 1945 ve věci Jawdat Badawi Sha’ban v. Commissioner for Migration and Statistics. ${ }^{68}$ Soud uvedl, že transjordánská státní příslušnost je odlišná od palestinské, a tudíž jsou nositelé těchto občanství vůči sobě navzájem cizinci, a proto Transjordánsko musí vůči Palestině vystupovat jako zahraniční stát. 69

63 FLOURNOY, R. - HUDSON, M. A Collection of Nationality Laws of Various Countries as Contained in Constitutions, Statutes and Treaties. New York: Oxford University Press, 1929, s. 298-303.

64 FLOURNOY - HUDSON, c. d., s. 225.

65 LEAGUE OF NATIONS, Trans-Jordan Memorandum. In: The Israeli-Palestinian Conflict. Interactive Database Beta [online] 1922-09-23 [cit. 2010-12-22]. Dostupné na: https://ecf.org.il/issues/issue/233.

66 BENTWICH, N. c. d. s. 405.

67 PAROLIN, G. Citizenship in the Arab World, Kin, Religion and Nation-State. Amsterdam: Amsterdam University Press, 2009, s. 86.

68 Annotated Law Reports, 1946, Vol. 1, s. 116.

69 QAFISHEH, c. d., s. 3-4. 


\section{STÁTNÍ OBČANSTVÍ ARABSKÝCH OBYVATEL ŽIJÍCÍCH NA ÚZEMÍ MANDÁTU PALESTINA OD UDÁLOSTI VZNIKU STÁTU IZRAEL DO VYHLÁŠENÍ NEZÁVISLOSTI PALESTINY}

Ke vzniku ,palestinského státního občanství“ z dnešního úhlu pohledu70 mělo dojít v návaznosti na proces mírových jednání v Oslu na počátku devadesátých let. Vytvoření legislativy související s udělováním a kritérii pro žádost o palestinskou státní př́slušnost bylo nutné z řady důvodů, z nichž některé souvisely již s událostí vzniku státu Izrael, jiné s událostmi pozdějšími, především s aktem jednostranného vzdání se nároku na území Západního břehu ze strany Jordánska v roce 1988.

K rozdělení mandátu Palestina ovšem došlo spíše důsledkem válečného konfliktu či v důsledku výkonu práva na sebeurčení židovských obyvatel nežli přímo prostřednictvím rezoluce 181 (II). Mezi aktéry sporu nebyl vytvořen žádný kompromis či mírová smlouva implementující předmětnou rezoluci. Britská správa mandátu skončila jednostrannou notifikací o ukončení správy mandátu Velkou Británií OSN.

V důsledku vyhlášení nezávislosti státu Izrael v roce 1948, aniž by zároveň vznikl na zbývajícím území bývalého mandátu Palestina arabský stát, došlo k faktickému rozdělení či rozštěpení jedné národnostní skupiny tamních arabských obyvatel a tím i k narušení trvalých vazeb mezi členy této skupiny. Arabští obyvatelé žijící na území státu Izrael se stali občany státu Izrael. K iniciaci vzniku nového arabského státu došlo teprve v období mezi koncem 80 . a počátkem 90 . let 20. století. Arabští obyvatelé dnešního Západního břehu se stali občany Jordánska. Obyvatelé žijící na území státu Izrael získali izraelskou státní příslušnost. Naopak obyvatelé Pásma Gazy zůstali de iure občany Palestiny dle úpravy Palestine Order-in Council z roku 1922, de facto byli ovšem osoby bez (účinné) státní příslušnosti (s jednou výjimkou, a sice byly jim vystaveny cestovní dokumenty). Samostatnou skupinu představují arabští uprchlíci, kteří jsou pod přímou ochranou OSN, ale nejsou a v současné době ani nemohou být nositeli žádné státní př́slušnosti. ${ }^{71}$ V souvislosti s ozbrojeným konfliktem válečných let 1948-1949 došlo $\mathrm{k}$ přesunu necelých tři čtvrtě milionu arabských obyvatel z území státu Izrael do Jordánska, Libanonu, Sýrie, Egypta.

\subsection{SPOJENÍ ZÁPADNÍHO BŘEHU S JORDÁNSKEM}

Od roku 1948 do roku 1967 vykonávalo Jordánsko správu dnešního palestinského Západního břehu. V roce 1949 byl změněn jordánský zákon o státním občanství z roku 1928 a ve znění této novely bylo upraveno, že arabští obyvatelé bývalého mandátu Palestina žijící na území Západního břehu se považují za obyvatelstvo Jordánska a ve všech ohledech k nim bude přistupováno jako k jordánským státním příslušníkům. Ve znění nové jordánské ústavy z roku $1952^{72}$ bylo stanoveno, že Západní břeh a Transjordánsko jsou spojeny v Jordánské hášimovské království. Spojení území

\footnotetext{
70 KHALIL, c. d. s. 13, 19-20.

71 Tamtéž s. 23-24.

72 Jordan's Constititution of 1952 with Amandaments through 2011. [online] 2019. [cit. 2019-03-12]. Dostupné na: https://www.constituteproject.org/constitution/Jordan_2011.pdf.
} 
na obou stranách řeky Jordánu trvalo z právního hlediska do roku 1988, kdy došlo k jejich rozdělení. ${ }^{73} \mathrm{~V}$ roce 1954 bylo uděleno prostřednictvím čl. 3 zákona č. 6/195474 státní občanství jak arabským obyvatelům Západního břehu, tak uprchlíkům, kteří se na území Západního břehu uchýlili. ${ }^{75}$ Čl. 2 téhož zákona ovšem rozlišoval dva typy státního občanství v Jordánsku. První kategorií bylo jordánské státní občanství, jež bylo uděleno žadatelům arabského původu, kteří se narodili na území jordánského království, resp. na části území mandátu Palestiny (z pohledu mezinárodního práva) okupovaného vojenskou silou, a druhou kategorií bylo občanství arabských osob ,vypovězených z vlasti“. ${ }^{76}$ V roce 1988 Jordánsko v souvislosti s vyhlášením Deklarace nezávislosti státu Palestina ${ }^{77}$ striktně zrušilo státní občanství osob „,vypovězených z vlasti“ a tím velká část obyvatel žijících na území Západního břehu přestala být nositelem této státní př́slušnosti udělené Jordánskem.

\subsection{EGYPTSKÁ SPRÁVA PÁSMA GAZY}

Pásmo Gazy na rozdíl od Západního břehu nebylo nikdy k Egyptu připojeno, naopak zůstalo samostatnou entitou. Egyptská vláda přijala pro Pásmo Gazy základní zákon v roce $1955,{ }^{78}$ který v žádném ohledu neobsahuje pojem ,palestinský obyvatel, resp. občan“ či „,palestinské občanství“, tento zákon užívá termín „obyvatelé Gazy“ ${ }^{79}$ Teprve v roce 1962 přijetím Vyhlášení ústavního pořádku ${ }^{80}$ pro Gazu byl zdůrazněn arabský element charakterizující Pásmo Gazy a palestinský národ. Podle čl. 1 tohoto ústavního pořádku je Gaza „neviditelnou součástí Palestiny“ a „lidé Gazy jsou součástí arabského národa“, nikoliv ovšem palestinského národa. Na druhé straně v několika dalších článcích tohoto zákona je zmíněn termín „Palestinci“. Arabští obyvatelé Pásma Gazy získali cestovní doklady vystavené Egyptem, ovšem nikoliv jako egyptští občané, Egypt tento postup od počátku odmítal. V praxi tak nedocházelo k asimilaci obyvatel Gazy s Egypt'any.

\footnotetext{
73 Srov. KHALIL, c. d., s. 22.

74 KINGDOM OF JORDAN. Law No. 6 of 1954 on Nationality (last amanded 1987). In: UNHCR REFWORLD [online] 2019. [cit. 2019-03-12]. Dostupné na: https://www.refworld.org/docid/3ae6b4ea13.html.

75 GRIEF, c. d., s. 183-185.

76 Pozn.: Khalil překládá odpovídající termín z arabského jazyka výrazem „expatriates“, KHALIL, c. d., s. 24. Basic Law for Gaza Strip No. 255, 1955. Dostupné na: Official Gaza Strip No. 304, 25. 02. 1958.

77 PALESTINIAN DECLARATION OF INDEPENDENCE (ANEX III) In: The Israeli-Palestinian Conflict, Interactive Database Beta [online] 1988-11-14. [cit. 2019-12-22]. Dostupné na: https://ecf.org.il/issues /issue/12.

78 Basic Law for Gaza Strip. No. 255, 1955. In: The Official-Gaza Strip No. 304. 25. 2. 1958, Art. 23.

79 Pozn.: Khalil překládá odpovídající termín z arabského jazyka výrazem ,people of Gaza“, KHALIL, c. d. s. 25.

80 Proclamation of the Constitutional Regime for Gaza Strip of 1962. In: The Official Gazette. Gaza Strip, No. 675. 29.3. 1962
} 


\subsection{IZRAELSKÁ OKUPACE PO ŠESTIDENNÍ VÁLCE}

Po konci šestidenní války přistoupil stát Izrael k vojenské okupaci ${ }^{81}$ území Západního břehu. Stát Izrael svůj postoj označuje termínem , výkon kontroly vůči spornému území“ $82 \mathrm{~V}$ nauce lze nalézt nap̌r. i označení této právní skutečnosti termínem „kolonizace“. 83

Ve spojení s událostmi šestidenní války proběhla druhá uprchlická vlna zahrnující přibližně čtvrt milionu osob arabského původu, tyto osoby a jejich potomci nemají podle izraelské a palestinské legislativy možnost návratu a repatriace z důvodu, že nesplňují kritéria pro nabytí státního občanství v těchto státech. ${ }^{84}$

V souvislosti s okupací Západního břehu a přítomností jednotek izraelské armády došlo v praxi i k zásadním zásahům vůči arabským občanům státu Izrael žijícím na tomto území, kteří se nebyli schopni prokázat se svými legitimacemi vystavenými státem Izrael od roku 1953. ${ }^{85}$ Své průkazy údajně museli odevzdat příslušníkům izraelské armády. Tento postup měl být nástrojem $\mathrm{k}$ přípravě realizace pozdější novely ${ }^{86}$ roku 1971 zákona upravující státní občanství (Nationality Law, 5712-1952), ${ }^{87}$ kterou došlo ke zrušení izraelské státní příslušnosti osob bez dokladů, a v návaznosti na to bylo těmto osobám uděleno pouze povolení k trvalému pobytu. K odstranění „bezdomovectví“ arabských obyvatel došlo až v roce 1980, kdy byl přijat zmírňující předpis, podle něhož bylo izraelské občanství uděleno všem arabským obyvatelům žijícím na území Izraele, ovšem nikoliv na okupovaném území Západního břehu, bez nutnosti naplnění dalších podmínek. ${ }^{88}$

Právo jednotlivce na státní občanství je chráněno ustanovením čl. 15 Všeobecné deklarace lidských práv ${ }^{89}$ z roku 1948, podle něhož má každý právo na státní př́íslušnost a nikdo nesmí být svévolně zbaven své státní příslušnosti ani práva státní příslušnost

81 International Commission of Jurists. Legal Consequences of the Construction of a Wall in the Occupied Palestinian Territory. In: The International Federation for Human Rights (FIDH) and the International Commission of Jurists. [online] 2003. [cit. 2018-12-23]. Dostupné na: https://www.fidh.org/IMG/pdf/il2302a.pdf.

82 Israel Supreme Court of Justice. The Levy Commission Report on the Legal Status of Building in Judea and Samaria. [online] 2012 [cit. 2018-12-23]. Dostupné na: https://israelipalestinian.procon.org/sourcefiles /The-Levy-Commission-Report-on-the-Legal-Status-of-Building-in-Judea-and-Samaria.pdf.

83 Např. KHALIL, c. d., s. 27, či PAPPÉ, I. Zionism as a Colonialism: A Comparative View of Diluted Colonialism in Asia and Africa. In: LUBIN, A. - GOLDSTEIN, A. Settler Colonialism. Durham: Duke University Press, Vol. 107, Num. 4 [online] 2008 [cit. 2018-12-23]. Dostupné na: https://read.dukeupress.edu /south-atlantic-quarterly/article/107/4/611/3404/Zionism-as-Colonialism-A-Comparative-View-of-Diluted.

84 KHALIL, c. d. s. 27.

85 Na základě zákona z roku 1953, ISRAEL. Nationality Law. 5712-1952, c. d.

86 HARPAZ, J. - HERZOG, B. Report on Citizenship Law: Israel. In: Global Citizenship Observatory. Edingurgh: Edinburgh University Law School. [online] 2008 [cit. 2018-12-23]. Dostupné na: http://cadmus.eui .eu/bitstream/handle/1814/56024/RSCAS_GLOBALCIT_CR_2018_02.pdf?sequence=1\&isAllowed=y.

87 ISRAEL NATIONALITY LAW In: UNHCR REFWORLD [online] 13. 07. 1953. [cit. 2019-12-22]. Dostupné na: https://www.refworld.org/docid/3ae6b4ec20.html.

88 Tamtéž.

89 UN. Universal Declaration of Human Rights. A/217/III [online] 1948 [cit. 2019-12-22]. Dostupné na: https:/www.un.org/en/development/desa/population/migration/generalassembly/docs/globalcompact/A _RES_217(III).pdf.

OSN. Všeobecná deklarace lidských práv [online] 1948,[cit. 2018-12-23]. Dostupné na: http://www .lidskaprava.cz/uploads/03_dokumenty/04_uvod/00_VDLP_UDHR-.pdf 
změnit. Všeobecná deklarace lidských práv byla přijata Valným shromážděním OSN a dle znění své preambule je společným cílem všech národů a států. Tato deklarace měla doporučující povahu, byla právně nezávazným dokumentem, měla ovšem povahu legis ferendae. V souvislosti s pozdějším vývojem státy přijaly ustanovení na ochranu lidských práv a svobod do svých ústav a do univerzálních i partikulárních mezinárodních smluv na ochranu lidských práv, zejména do Mezinárodního paktu o lidských právech. Ustanovení Všeobecné deklarace lidských práv se později přeměnila v závazná smluvní a obyčejová pravidla. ${ }^{90}$

\section{6. „PALESTINSKÉ OBČANSTVÍ“ PO VYHLÁŠENÍ NEZÁVISLOSTI PALESTINY}

Z pohledu mezinárodního práva není snadné odpovědět na otázku, zda je, či není Palestina státem, tím spíše, že z pohledu nauky mezinárodního práva lze nalézt celou řadu příznivců protichůdných názorů. Bylo by poměrně problematické se v rozsahu subkapitoly tohoto článku detailně zabývat hledáním odpovědi na tuto otázku a téma uspokojivě vyčerpat. Autorka se domnívá, že je nutné alespoň stručně nabídnout odpověd’ na otázku státnosti Palestiny s ohledem na téma této subkapitoly, jímž je „soudobé palestinské občanství“, tím spíše, že občanství je svým obsahem úzce spjato se státem.

Za první krok směřující k transformaci Hnutí za osvobození Palestiny ${ }^{91}$ na stát lze považovat akt vyhlášení Deklarace nezávislosti v roce 1988, ${ }^{92}$ která zároveň nepřímo představovala i uznání práva státu Izrael na svou existenci. ${ }^{93} \mathrm{~K}$ výslovnému vzájemnému uznání mezi Hnutím za osvobození Palestiny jakožto zástupcem palestinského lidu a státem Izrael došlo v roce 1993 podpisem dokumentu Deklarace principů, ${ }^{94}$ po tomto uznání následovala jednání mezi těmito aktéry, jejichž předmětem jsou okupovaná území, která stát Izrael na rozdíl od převažující části mezinárodního společenství označuje termínem „sporná území“.95 V roce 2012 rovněž došlo k přijetí Palestiny

90 POTOČNÝ - ONDŘEJ, c. d., s. 94-95.

91 V roce 1974 bylo Hnutí za osvobození Palestiny v čele s Jásirem Arafatem uznáno Valným shromážděním OSN jako orgán, který reprezentuje a hájí zájmy palestinského lidu žijícího na území dlouhodobě okupovaném státem Izrael, viz UNITED NATIONS. General Assembly 2268 ${ }^{\text {th }}$ Plenary Meeting. Question of Palestine. [online] 1974. [cit. 2019-03-12]. Dostupné na: https://unispal.un.org/DPA/DPR/unispal .nsf/0/2A1CF8A3EA4D1F0385256230005AFFEE.

92 Srov. KHALIL, c. d., s. 34.

93 Tamtéž, s. 20.

94 ISRAEL MINISTRY OF FOREIGN AFFAIRS. Declaration of Principles on Interim Self-Government Arrangements [online] 13.09. 1993 [cit. 2019-12-22]. Dostupné na: https://mfa.gov.il/mfa/foreignpolicy /peace/guide/pages/declaration\%20of\%20principles.aspx.

95 Zatímco k aktu vzájemného uznání mezi státem Izrael a Hnutím za osvobození Palestiny a rovněž k politickému uznání Palestiny jakožto státu došlo řadou států již v roce 1988, Izrael Palestinu jako stát nikdy neuznal.

UNITED NATIONS. General Assembly Resolutions 43/175 [online] 1988 [cit. 2019-03-12]. Dostupné na: http://www.un.org/documents/ga/res/43/a43r175.htm.

UNITED NATIONS. General Assembly Resolutions 43/176 [online] 1988 [cit. 2019-03-12]. Dostupné na: http://www.un.org/documents/ga/res/43/a43r176.htm. 
jakožto státu na půdu Valného shromáždění OSN, kde má Palestina postavení nečlenského státu s pozorovatelským statusem..$^{96}$ Autorka se domnívá, že uznání Palestiny státem at' už ze strany Valného shromáždění či ze strany třetích států je toliko aktem politického uznání, jehož prostřednictvím ovšem nelze odpovědět na otázku, zda je Palestina státem z pohledu mezinárodního práva, dle jehož pramenů musí stát vykazovat určité znaky.

Kritéria státnosti podle mezinárodního práva lze nalézt v čl. 1 Úmluvy o právech a povinnostech států (Montevidejské úmluvy z roku 1933), ${ }^{97}$ která, ačkoliv se jedná svou povahou o mezinárodně právní partikularismus, obsahuje obecné znaky, jež musí splňovat každá entita, již lze považovat z objektivního úhlu pohledu za stát. Těmito znaky jsou stálé obyvatelstvo, vymezené území, vláda (výkon veřejné moci) a způsobilost vstupovat do vztahů s jinými státy. Autorka se domnívá, že u minimálně dvou znaků, konkrétně znaku území a nerušeného výkonu veřejné moci, je přinejmenším sporné, zda jsou zcela naplněny. Autorka se domnívá, že by bylo možné považovat Palestinu za stát ve stadiu zrodu, in statu nascendi. Není pochyb, že stát Izrael brání tomu, aby došlo k plnému rozvinutí palestinské státnosti, nicméně objektivně vzato by každý stát měl být schopen se mocensky prosadit i v případě (eventuálně protiprávního) působení jiného státu.

Jedním ze základních kritérií pro nezávislý stát je dle mezinárodního práva i skutečnost, že stát není ve své výlučné suverenitě omezován státem jiným..$^{98}$ Palestina i nadále nemá plnou teritoriální suverenitu vůči území Západního břehu, které je od roku 1967 do současnosti v režimu vojenské okupace. Na palestinském území Pásma Gazy došlo sice k evakuaci izraelských civilistů a odsunu izraelských bezpečnostních složek v roce 2005, ovšem již od roku 2007 - po vítězství hnutí Hamás v tamních volbách v roce 2006 - přistoupil stát Izrael společně s Egyptem k blokádě tohoto území. Blokáda území sice nepředstavuje zásah do územní suverenity státu, ale je s ní spojena celá řada praktických omezení.

Pro Hnutí za osvobození Palestiny bylo stěžejní hájit zájmy palestinského lidu bez ohledu na místo jejich obvyklého pobytu, ${ }^{99}$ jednotlivci identifikující se jako členové palestinského národa jsou poznamenáni fragmentací této skupiny a nacházejí se kromě území Pásma Gazy a Západního břehu i v okolních arabských státech, v uprchlických táborech spravovaných OSN. Další dvě samostatné skupiny tvoří arabští občané státu Izrael a dále palestinští obyvatelé s trvalým pobytem na území Jeruzaléma bez izraelské státní příslušnosti.

UNITED NATIONS. General Assembly Resolutions 43/177 [online] 1988 [cit. 2019-03-12]. Dostupné na: http://www.un.org/documents/ga/res/43/a43r177.htm.

96 UNITED NATIONS. General Assembly Resolutions 67/19 [online] 2012 [cit. 2019-12-23]. Dostupné na: https://undocs.org/A/RES/67/19.

97 The International Conferences of American States, First Supplement, 1933-1940, s. 121.

98 ČEPELKA, Č. - ŠTURMA, P., c. d, s. 51-52. Srov. KHALIL, c. d., s. 39-40.

99 KHALIL, c. d., s. 15, 41. 


\subsection{FRAGMENTY SOUVISEJÍCÍ PALESTINSKÉ LEGISLATIVY}

K odstranění nejasností ve smyslu, kdo může být z právního hlediska považován za člena palestinského národa, nedošlo ani přijetím základního zákona Palestinské správy v roce 2002 (Basic Law for the Palestinian Authority 2002), ${ }^{100}$ vytvořeného palestinskou legislativní radou. Podle jeho čl. 1 je palestinský lid součástí arabského národa (bez dalšího upřesnění, kdo je Palestincem). K přímé volbě prezidenta dle tohoto zákona dochází palestinskými „lidmi“ (pozn. nikoliv občany), dle jiného ustanovení policejní a bezpečnostní složky musí sloužit všemu „lidu“. Tento zákon zahrnuje toliko palestinský „lid“ žijící na území Západního břehu a Pásma Gazy ${ }^{101}$ a tím i vylučuje ostatní osoby žijící mimo toto území, které se ovšem za Palestince bezpochyby považují, především tedy palestinské uprchlíky.

Definice ,palestinského lidu“ byla částečně upřesněna v návrhu palestinské ústavy z let 2001 až 2003 (The Draft Palestinian Constitution, 2001-2003), ${ }^{102}$ podle níž jsou do této množiny zahrnuti obyvatelé žijící na palestinských územích, ovšem bez další specifikace, co je považováno za palestinské území. Není tedy jasné, zda se jedná toliko o Západní břeh a Pásmo Gazy, či o území bývalého Mandátu Palestina jako celek, s ohledem na to, že dle čl. 8 je Jeruzalém hlavním městem Palestiny, rovněž bez další specifikace, zda jako celek či jen jeho východní část). ${ }^{103}$

V souvislosti s jednáním v Oslu na počátku devadesátých let lze zaznamenat i první krok ve vztahu k řešení „,bezdomovectví“ arabských obyvatel Západního břehu, Pásma Gazy a východní části Jeruzaléma, ${ }^{104}$ kteří nezískali izraelskou státní příslušnost na základě výše uvedené a v pořadí čtvrté zmírňující novely v roce 1980 izraelského předpisu (Nationality Law, 5712-1952, 4/1980). ${ }^{105}$ Palestinská národní správa začala po mírových jednáních v Oslu vydávat osobám majícím místo svého pobytu na předmětných územích palestinské cestovní doklady, ${ }^{106}$ které ovšem nelze zaměňovat s aktem uděle-

100 Palestinian Legislative Council. 2002 Basic Law [online] 29. 03.2002 [cit. 2019-12-22]. Dostupné na: https://www.palestinianbasiclaw.org/basic-law/2002-basic-law.

101 The Palestinian Basic Law. 2002, amanded in 2003 [online] 29. 03.2002 [cit. 2019-03-12]. Dostupné na: https://www.palestinianbasiclaw.org/basic-law/2002-basic-law.

102 PALESTINIAN CONSTITUTIONAL COMMITTEE. The Draft of the Palestinian Constitution [online] 14. 02. 2001 [cit. 2019-03-12]. Dostupné na: https://www.pcpsr.org/en/node/487.

103 The Draft of the Palestinian Constitution [online] 2001 [cit. 2019-03-12]. Dostupné na: http://www.pcpsr .org/en/node/487.

104 Arabští obyvatelé žijící ve Východním Jeruzalémě jsou nositeli statusu osob majících povolení k trvalému pobytu. Jejich postavení odpovídá pozici cizinců, kteří se usídlili v jiné zemi, jako takoví mají právo volit ve volbách do místního zastupitelstva, ale nikoliv do parlamentu. Pakliže splní určitá kritéria, kterými jsou přísaha loajality státu Izrael, prokáží znalost hebrejštiny a doloží, že nejsou občany jiné země, mohou požádat o izraelské občanství. Velké množství Arabů ovšem o izraelské občanství nepožádalo z politických důvodů, zejména proto, že přijetím izraelského občanství by i nepřímo uznali, že Izrael je územním suverénem města Jeruzaléma jako celku.

NAPOLITANO, P. Jerusalem: Heart of the Israeli-Palestinian Conflict. In: Policiy Briefing. Brussels: Directorate General for External Policies of Union Policy Department, s. 4 [online] 2012 [cit. 2019-03-12]. Dostupné na: http://www.europarl.europa.eu/RegData/etudes/briefing_note/join/2012/491443 /EXPO-AFET_SP\%282012\%29491443_EN.pdf.

105 ISRAEL NATIONALITY LAW In: UNHCR REFWORLD [online] 13. 07. 1953 [cit. 2019-12-22]. Dostupné na: https://www.refworld.org/docid/3ae6b4ec20.html.

106 KHALIL, c. d., s. 35. 
ní státního občanství (obdobně jako Egypt vystavoval od roku 1955 cestovní doklady obyvatelům Pásma Gazy, nepřijal je ovšem za své občany). Naopak ve vztahu k arabským občanům státu Izrael došlo po jednáních v Oslu k určitému distancování Palestinskou národní správou. Arabové žijící na území státu Izrael jsou nositelé izraelské státní př́ślušnosti a jsou z právního hlediska vyloučeni ${ }^{107} \mathrm{z}$,,množiny palestinského národa“, v praxi tvoří na území státu Izrael národnostní menšinu.

Na rozdíl od alespoň dílčího (a ne zcela vyčerpávajícího) stanovení, kdo je a kdo není z právního hlediska Palestincem, ${ }^{108}$ neexistuje do dnešní doby platný a účinný předpis, který by reguloval otázky související s nabýváním palestinské státní příslušnosti. Palestinská národní správa připravila v roce 1995 návrh právního předpisu (Draft Palestinian Citizenship Law) ${ }^{109}$ který by otázky spojené s problematikou státního občanství v Palestině upravoval, nicméně jako zákon přijat nebyl. Z pohledu právní teorie je ovšem možné rámcově vycházet z tohoto návrhu zákona.

Podle ustanovení návrhu zákona o palestinské státní příslušnosti z roku $1995^{110}$ je občanem Palestiny ten, kdo je držitelem palestinských dokladů vystavených před rokem 1948 a zároveň není osobou židovského původu. Dále kdokoliv, kdo má palestinského otce, rovněž ten, kdo se narodil na území Palestiny palestinské matce, a to i pokud je státní příslušnost jeho otce neznámá. Dále ten, kdo se narodil na území Palestiny (bez dalšího), a konečně ten, kdo se narodil mimo území Palestiny palestinské matce a otci, jehož státní příslušnost není známá, a využije možnost opce palestinského občanství současně s vyjádřením úmyslu trvalého usídlení se v Palestině do jednoho roku po dosažení osmnácti let, přičemž orgánem příslušným k vyřizování žádostí o udělení palestinského občanství je palestinské ministerstvo vnitra. Nositelem palestinského občanství se žadatel stane, pakliže ministr do jednoho roku od doručení žádosti nerozhodne o jejím zamítnutí. 111

Palestinské občanství podle tohoto návrhu zákona tedy vychází z principů jus soli, jus sangvinius a je možné občanství získat i naturalizací, pakliže alespoň matka má palestinskou státní př́ílušnost.

V případě, že by nositelé palestinského občanství chtěli získat izraelské občanství, museli by splnit jednu ze tří podmínek, a sice bud’ listinnou formou ${ }^{112}$ prokázat, že byli v roce 1949 registrovaní jako obyvatelé a žili na území Izraele k datu 14. 6. 1952, nebo že na izraelské území v uvedeném období legálně vstoupili, a konečně podle pozdější novely

107 Stejně jako palestinští uprchlíci v uprchlických táborech pod správou OSN, jakož jednotlivci, kteří původně žili na území dnešních států Izrael a Palestina, ale přesídlili do sousedních arabských zemí a byli s tamními obyvateli asimilováni. Tyto dvě skupiny spolu s izraelskými arabskými občany tedy byly z hlediska státní př́íslušnosti vyloučeny z palestinského národa, protože nemohou nabýt občanství státu Palestina, nicméně zůstávají i nadále členy širšího arabského národa.

108 The Palestinian Basic Law. c. d., The Draft of the Palestinian Constitution. c. d.

109 KHALIL, c. d., 41.

110 Draft Palestinian Nationality Law and the Jordanian Nationality Law, 6/1954. KHALIL, c. d., s. 40-42. DAVIS, U. JINSIYYA versus MUWATANA: The question of citizenship and the state in the Middle East: the cases of Israel, Jordan and Palestine. In: Arab Studies Quaterly. New York: JSTOR, vol. 17, No. 1/2, s. 19-50 [online] 1995 [cit. 2019-03-12]. Dostupné na: https://www.jstor.org /stable/41858111?read-now=1\&seq=1\#metadata_info_tab_contents.

111 KHALIL, c. d., s. 42.

112 Čestné prohlášení není akceptováno jako dostačující. 
příslušných předpisů z roku 1968 mají Palestinci možnost požádat o izraelské občanství nejvýše v období tří let po dosažení osmnáctého roku věku, pokud zároveň prokáží trvalý pobyt na území Izraele nepřetržitě po dobu pěti let před podáním žádosti o izraelské občanství. ${ }^{113}$

\section{ZÁVĚR}

Ve vztahu ke státnímu občanství obyvatel dnešního státu Izrael a území Palestiny došlo $\mathrm{v}$ uplynulých sto letech $\mathrm{k}$ řadě proměn. Palestinské státní občanství v původním slova smyslu se stalo občanstvím izraelským, a naopak k právně účinnému vzniku palestinského státního občanství do dnešního dne nedošlo. Situace je obzvlášt' složitá u osob arabského původu, kde v praxi došlo k několika zásadním změnám v závislosti na místě jejich bydliště. Stalo se tak proto, že nedošlo současně ke vzniku židovského a arabského státu, tak jak navrhovala rezoluce Valného shromáždění 181 (II), a proto po určitou dobu byli arabští obyvatelé žijící na Západním břehu dočasně občany Jordánska a obyvatelé Pásma Gazy byli bez účinné státní příslušnosti s tím, že určité praktické otázky týkající se Pásma Gazy řešilo egyptské zákonodárství.

Na přelomu dvacátého a dvacátého prvního století došlo v souvislosti s jednáními v Oslu, americkém Camp Davidu a egyptské Tabě ke vzájemnému uznání státu Izrael a Hnutí pro osvobození Palestiny. V následujících necelých dvaceti letech ovšem nedošlo k žádnému zásadnímu posunu v řešení otázek konfliktu mezi těmito stranami, ani ke vzájemnému uznání státu Izrael a Palestiny v pozici státu. Ačkoliv se z pohledu mezinárodního práva jedná spíše o „,budoucí stát“, je na půdě OSN Palestina za stát považována. Teoreticky by tudíž stát Izrael mohl Palestinu za stát z politického hlediska uznat. Je ovšem zřejmé, proč k tomu Izrael nepřistoupil, a nic nenasvědčuje, že by se to mělo v nejbližší době změnit. Tyto subjekty tak i nadále na půdě OSN vedle sebe existují, ačkoliv se vzájemně neuznávají, podobně jako i jiné arabské státy neuznávají stát Izrael.

Palestinské orgány jsou při výkonu svých práv omezeny ${ }^{114}$ státem Izrael v podobě již po více než padesát let trvající vojenské okupace. Palestina je uznána jako nečlenský stát OSN s pozorovatelským statusem a je jako stát členem řady mezinárodních organizací. Palestinský zákonodárný orgán nepřijal právně účinný předpis upravující režim státního občanství, obyvatelé území státu Palestina, tedy Západního břehu a Pásma Gazy, disponují toliko cestovními doklady. ${ }^{115}$ Po právní stránce nelze v současnosti jednoznačně určit, kdo je či bude nositelem palestinské státní příslušnosti. Palestinští uprchlíci čítající v dnešní době přes pět milionů, ačkoliv se cítí býti Palestinci z důvodu svého původního spojení s územím dnešního státu Izrael a územím Palestiny, nejsou nositeli žádné státní příslušnosti a požívají mezinárodní ochranu pod záštitou OSN.

\footnotetext{
113 APFEL, A. Israeli Arabs: History \& Overview. In: Jewish Virtual Library [online] 2016 [cit. 2019-03-12]. Dostupné na: http://www.jewishvirtuallibrary.org/history-and-overview-of-israeli-arabs.

114 Což by mohlo představovat překážku mezinárodně právní subjektivity státu dle Montevidejské úmluvy z roku 1933

115 Které jsou většinou mezinárodně uznávané.
} 
Státní občanství arabských obyvatel žijících na území dnešního státu Izrael (s výjimkou Východního Jeruzaléma) bylo jako jediné (v rámci původní ucelené množiny arabských obyvatel dotčeného území) účinně právně stanoveno, a sice tak, že arabští obyvatelé státu Izrael bez ohledu na jejich dílčí etnickou příslušnost získali izraelské občanství. V polovině roku 2018 byl přijat nový izraelský základní zákon s názvem „Izrael, národní stát židovského lidu“"116 (Basic Law: Israel - the Nation State of the Jewish People), ${ }^{117}$ který představuje zásadní změnu co do úředních jazyků. V dikci tohoto zákona se arabština stává jazykem národnostní menšiny a její užívání bude stanoveno budoucím zvláštním zákonem. Nejen arabští obyvatelé především drúzského původu, ale i jiní zejména sekulární židovští obyvatelé státu Izrael hodnotí tuto úpravu velmi negativně a předjímají další nepříznivý vývoj, který by mohl změnit postavení arabských občanů státu Izrael.

Jakýkoliv krok hromadného odnímání státního občanství vůči celé skupině obyvatel je v mezinárodním právu silně nežádoucím jevem. Arabští obyvatelé dnešního palestinského území byli touto skutečností již jednou postiženi na konci osmdesátých let, kdy jim Jordánsko státní příslušnost odebralo.

Pakliže by mělo do budoucna hypoteticky dojít ke změně státního občanství vůči určité skupině obyvatel státu Izrael, bylo by nezbytné, aby v souladu s mezinárodním právem měli dotčení obyvatelé po určité období možnost na základě dvoustranné mezinárodní smlouvy mezi zúčastněnými stranami optovat státní občanství, které by si sami zvolili.

Dle názoru autorky v současné době po právní stránce nic nenasvědčuje k tomu, že by se stát Izrael připravoval na odejmutí státního občanství určité skupině osob, výše zmiňovaný základní zákon sám o sobě nemá vliv na dřivější a nadále platnou legislativu, která státní občanství arabských obyvatel státu Izrael upravuje.

Mgr. Veronika D’Evereux, Ph.D.

Právnická fakulta Univerzity Karlovy

devereux@seznam.cz

116 Pozn. překlad autorky.

117 ISRAEL. Basic Law: Israel - the Nation State of the Jewish People. [online] 2018. [cit. 2019-03-12]. Dostupné na: https://knesset.gov.il/laws/special/eng/BasicLawNationState.pdf. 